\title{
PENGARUH EDUKASI KESEHATAN MELALUI MEDIA SOSIAL LINE TERHADAP SIKAP REMAJA PUTRI TENTANG PENCEGAHAN ANEMIA DEFISIENSI BESI DI SMP NEGERI 2 RENDANG
}

\author{
Ni Putu Tri Purnama Dewi ${ }^{1}$ I Made Dwie Pradnya Susila², Gede Arya Bagus Arisudhana ${ }^{3}$, Ni Made \\ Risna Sumawati ${ }^{4}$ \\ STIKES Bina Usada Bali ${ }^{1234}$ \\ e-mail: 2dwiepradnya@gmail.com
}

\begin{abstract}
Girls adolescent are in high risk of developing anemic. The high prevalence of the girl adolescents, proves that the low awareness of iron deficiency anemia. Education is one way to increase respondents' knowledge so that they can form positive attitudes and healthy behaviors. Social media can be used as an educational media that is quite effective in reaching young people. The purpose of this study was to determine the effect of health education through social media Line on the attitudes of adolescents about the prevention of iron deficiency anemia in SMP Negeri 2 Rendang. The research method used was quantitative pre-experimental design with One Group Pretest and Posttest Design. The population in the study were young women class VIII and XI in SMP Negeri 2 Rendang in the school year 2019/2020 with a sample of 105 students selected based on simple random sampling. Respondents received education twice a week for 5 weeks. The results showed that the attitudes of girl adolescents before being given education in sufficient category of $89.5 \%$ and after being given education was in good category of 19\%. From the Wilcoxon sign rank test statistical results obtained Zhitung $=6,151>$ Ztable $=1,645$ P value $=$ $0,000<\alpha$ 0.05. it can be concluded that education through social media line can influence the attitudes of girl adolescents about the prevention of iron deficiency anemia.
\end{abstract}

Keywords: anemia, education, social media, attitude, girl adolescents

\begin{abstract}
ABSTRAK
Remaja putri berisiko tinggi mengalami anemia. Tingginya prevalensi remaja putri, membuktikan bahwa rendahnya kesadaran akan anemia defisiensi besi. Pendidikan merupakan salah satu cara untuk meningkatkan pengetahuan responden sehingga dapat membentuk sikap positif dan perilaku yang sehat. Media sosial dapat dijadikan sebagai media pendidikan yang cukup efektif dalam menjangkau kaum muda. Tujuan penelitian ini adalah untuk mengetahui pengaruh pendidikan kesehatan melalui media sosial Line terhadap sikap remaja tentang pencegahan anemia defisiensi besi di SMP Negeri 2 Rendang. Metode penelitian yang digunakan adalah kuantitatif pre-experimental design dengan One Group Pretest and Posttest Design. Populasi dalam penelitian ini adalah remaja putri kelas VIII dan XI di SMP Negeri 2 Rendang tahun pelajaran 2019/2020 dengan jumlah sampel 105 siswa yang dipilih berdasarkan simple random sampling. Responden menerima edukasi dua kali seminggu selama 5 minggu. Hasil penelitian menunjukkan bahwa sikap remaja putri sebelum diberikan edukasi berada pada kategori cukup sebesar 89,5\% dan setelah diberikan edukasi berada pada kategori baik sebesar 19\%. Dari hasil statistik uji Wilcoxon sign rank test diperoleh Zhitung $=6,151>$ Ztabel $=1,645$ Nilai $\mathrm{P}=0,000<0,05$. dapat disimpulkan bahwa edukasi melalui media sosial dapat mempengaruhi sikap remaja putri tentang pencegahan anemia defisiensi besi.
\end{abstract}

Kata kunci: anemia, edukasi, media sosial, sikap, remaja putri

\section{PENDAHULUAN}

Anemia merupakan salah satu masalah kesehatan yang sering dijumpai di masyarakat di dunia terutama di negara berkembang seperti Indonesia. Anemia merupakan penyebab kecatatan kedua tertinggi di dunia. Penduduk dunia mengalami anemia dengan prevalensi secara global sekitar $51 \%$ dan sekitar 30\% atau 2,20 miliar orang tinggal di daerah tropis (Priyanto, 2018).

Anemia dapat dialami oleh semua kelompok umur dari balita hingga usia lanjut namun kelompok yang paling rentan mengalami anemia adalah remaja putri dan wanita usia subur. Kurang lebih terdapat 370 juta wanita di negara berkembang menderita anemia defisiensi besi dengan prevalensi sekitar $41 \%$ diantaranya wanita tidak hamil. Prevalensi anemia di 
Indonesia masih cukup tinggi (Fakhidah, Putri; 2016). Berdasarkan Survey Kesehatan Rumah Tangga (SKRT) tahun 2012 menunjukkan prevalensi anemia pada kelompok umur 10-18 tahun sebesar 57,1\%. Upaya pencegahan dan penanggulangan anemia dilakukan dengan memberikan asupan zat besi yang cukup ke dalam tubuh.

Hasil studi pendahuluan di SMP Negeri 2 Rendang menunjukkan bahwa pemahaman siswi terhadap upaya pencegahan anemia defisiensi besi masih belum cukup yang akan mempengaruhi sikap dan perilakunya. Salah satu upaya pencegahan anemia adalah dengan memberikan pendidikan kesehatan untuk meningkatkan pengetahuan dan membentuk sikap terhadap pencegahan anemia defisiensi besi (Kemenkes RI, 2016). Dalam memberikan Pendidikan kesehatan diperlukan media untuk menyampaikan informasi. Media sosial merupakan media yang ringkas dan menarik sehingga mempermudah penyampaian ilmu yang akan diberikan, mencakup berbagai ide pendapat gagasan dan konten dalam komunitas virtual serta mampu menghadirkan dan mentranslasikan cara berkomunikasi baru dengan teknologi yang sama sekali berbeda dari media tradisional (Yaumi, 2018). Line merupakan salah satu media sosial yang banyak dipergunakan teruatama oleh kalangan remaja. Saat ini terdapat 220 juta pengguna yang tergabung ke dalam aplikasi line di seluruh dunia dan di Indonesia sendiri terdapat 90 juta pengguna yang merupakan pengguna aktif (Pakar, 2018). Media sosial dapat memberikan pengaruh positif yaitu sebagai media komunikasi yang mudah, tempat promosi yang baik dan murah, tempat mencari dan berbagi informasi yang bermanfaat (Secsio, Putri, Nurwati, \& S, 2016). Sikap pada kelompok yang diberikan pendidikan kesehatan mengalami peningkatan setelah diberikan edukasi (Mariyaningsih, 2018). Edukasi setiap 2 kali seminggu dalam 5 minggu dapat meningkatkan kepatuhan konsumsi antiretroviral pada orang dengan HIV/AIDS (Arisudhana, 2017).

\section{METODE}

Penelitian ini adalah pre eksperimental kuantitatif dengan one group pretest and posttest design. Sampel dipilih menggunakan teknik simple random sampling dengan menggunakan kriteria inklusi dan eksklusi. Data dianalisis menggunakan uji statistik wilcoxon sign rank test.

\section{HASIL}

\section{Karakteristik Responden}

Tabel 1

Distribusi Frekuensi Umur Responden saat Menarche

\begin{tabular}{llll}
\hline No & Umur(th) & \multicolumn{2}{c}{ Hasil Penelitian } \\
& & $\mathrm{N}$ & $\%$ \\
\hline 1 & $\leq 13$ & 75 & 71.4 \\
2 & $>13$ & 30 & 28.6 \\
\hline & Total & 105 & 100 \\
\hline
\end{tabular}

Berdasarkan tabel 1 diatas didapatkan bahwa lebih banyak responden menarche saat berumur $\leq 13$ tahun yaitu sebesar $71.4 \%$ dan $28,6 \%$ pada usia $\geq 13$ tahun. Hal ini sejalan dengan teori bahwa umur menarche yang normal terjadi pada umur 11-13 tahun. Hal ini dipengaruhi oleh faktor keturunan, keadaan gizi dan kesehatan umum

\section{Siklus Menstruasi Responden}

Tabel 2

Distribusi Frekuensi siklus Mestruasi Responden

\begin{tabular}{lllc}
\hline No & Siklus Menstruasi & \multicolumn{2}{c}{ Hasil Penelitian } \\
& (hari) & N & $\%$ \\
\hline 1 & $\leq 35$ & 66 & 62.9 \\
2 & $>35$ & 39 & 37.1 \\
\hline & Total & 105 & 100 \\
\hline
\end{tabular}

Berdasarkan tabel 2 diatas menunjukkan lebih banyak responden mengalami siklus menstruasi selama $\leq 35$ hari yaitu sebesar $62.9 \%$ dan $37,1 \%$ dengan siklus menstruasi $>35$ hari. Hal ini juga sesuai dengan teori Attarchi, et. al., (2013) siklus menstruasi yang teratur adalah siklus menstruasi yang berada dalam interval 23-35 hari dengan perbedaan maksimum 7 hari antara siklus menstruasi yang terpendek dan yang terpanjang.

\section{Frekuensi Tanda dan Gejala Anemia Yang Pernah Dialami Responden}

Tabel 3

Distribusi Frekuensi tanda dan gejala anemia yang pernah dialami Responden

\begin{tabular}{llll}
\hline No & Tanda dan gejala Anemia & \multicolumn{2}{l}{ Hasil Penelitian } \\
& & N & $\%$ \\
\hline 1 & tidak ada & 9 & 8.6 \\
2 & 5L & 53 & 50.5 \\
3 & pusing & 7 & 6.7 \\
4 & cepat capek & 34 & 32.4 \\
5 & kelopak pucat & 1 & 1 \\
6 & lainnya & 1 & 1 \\
\hline & Total & 105 & 100 \\
\hline
\end{tabular}




\section{Vol. 16 No.2 Mei - Agustus 2021}

Berdasarkan tabel 3 menunjukkan $91.4 \%$ responden pernah mengalami gejala anemia diman yang terbanyak pernah mengalami $5 \mathrm{~L}$ yaitu sebesar $50.5 \%$, cepat capek $34 \%$. Hal ini sejalan dengan teori bahwa tanda dan gejala anemia yang paling sering dialami oleh remaja putri adalah 5L (Direktorat Jenderal Kesehatan Masyarakat, 2016a).

\section{Status Gizi Responden}

Tabel 4

Distribusi Frekuensi Status Gizi Responden

\begin{tabular}{llll}
\hline No & IMT & \multicolumn{2}{c}{ Hasil Penelitian } \\
& & N & $\%$ \\
\hline 1 & Kurus & 39 & 37.1 \\
2 & Normal & 60 & 57.1 \\
3 & gemuk & 6 & 5.7 \\
\hline & Total & 105 & 100 \\
\hline
\end{tabular}

Berdasarkan tabel 4 menunjukkan lebih banyak status gizi responden dalam katagori normal yaitu sebesar $57,1 \%$. Status gizi yang baik sangat mendukung kesehatan reproduksi terutama remaja yang sedang mengalami tumbung dan kembang yang pesat.

\section{Sikap Sebelum Diberikan Edukasi}

Tabel 5

Distribusi Frekuensi Sikap Remaja Putri Sebelum diberikan edukasi

\begin{tabular}{llll}
\hline No & Sikap Remaja Putri & Hasil Penelitian \\
& Pretest & N & $\%$ \\
\hline 1 & Cukup & 94 & 89.5 \\
2 & Baik & 9 & 10.5 \\
\hline & Total & 105 & 100 \\
\hline
\end{tabular}

Berdasarkan tabel 5 diatas dari 105 responden sebelum diberikan intervensi sebanyak 94 orang $(89.5 \%)$ sikap sasaran cukup.

\section{Sikap Setelah Diberikan Intervensi}

Tabel 6

Distribusi Frekuensi Sikap Remaja Putri Setelah diberikan edukasi

\begin{tabular}{llll} 
No & Sikap Remaja Putri & Hasil Penelitian \\
& Posttest & N & $\%$ \\
\hline 1 & Cukup & 85 & 81 \\
2 & Baik & 20 & 19 \\
\hline & Total & 105 & 100
\end{tabular}

Berdasarkan tabel 6 dari 105 responden setelah diberikan intervensi sebanyak 20 orang (19\%) sikap sasaran baik.

\section{Pengaruh Edukasi Kesehatan Melalui Media Sosial Line Terhadap Sikap Remaja Putri Tentang Pencegahan Anemia Defisiensi Besi}

Tabel 7

Hasil uji analisis Pengaruh Edukasi Kesehatan

Melalui Media Sosial

Terhadap Sikap Remaja Putri Tentang Pencegahan

Anemia

Defisiensi Besi di SMP N 2 Rendang

\begin{tabular}{lllll}
\hline Hasil Uji & Pretest & Posttest & $Z_{\text {hitung }}$ & $\begin{array}{l}P \\
\text { value }\end{array}$ \\
\hline Mean & 54.96 & 57.76 & & \\
\hline Median & 55.00 & 57.00 & & \\
\hline Minimum & 47 & 48 & 6.151 & 0.000 \\
\hline Maksimum & 65 & 67 & & \\
\hline $\begin{array}{l}\text { Standar } \\
\text { Deviasi }\end{array}$ & 4.067 & 4.300 & & \\
\hline
\end{tabular}

Dari hasil uji statistic wilcoxon sign rank test didapatkan $\mathrm{Z}_{\text {hitung }}=6.151>\mathrm{Z}_{\text {tabel }}=1.645$ Pvalue $=$ $0.000<\alpha 0.05$.

\section{PEMBAHASAN}

Hasil penelitian ini sejalan dengan penelitian Widantori (2019) yang menyatakan hasil bahwa sikap remaja putri sebelum diberi edukasi kurang mendukung sebesar $51.9 \%$.

Sikap responden yang tidak mendukung dalam penelitiannya karena masih banyak remaja putri yang tidak setuju terhadap konsumsi tablet tambah darah serta upaya pencegahan anemia, salah satu di antaranya adalah masih banyaknya remaja putri yang tidak mau mengonsumsi tablet tambah darah $(74,7 \%)$, serta $48,0 \%$ responden merasa bahwa selama menstruasi tidak perlu mengonsumsi tablet tambah darah. Hal ini disebabkan responden sebelumnya kurang terpapar informasi mengenai anemia defisiensi besi karena kurang maksimalnya penyuluhan kesehatan yang dilakukan petugas kesehatan.

Sikap remaja putri mengalami peningkatan setelah diberikan edukasi kesehatan melalui media sosial line. Sikap remaja putri sangat dipengaruhi oleh pengetahuan yang dimiliki oleh remaja putri itu sendiri. Remaja putri yang mendapatkan edukasi cenderung mempengaruhi sikapnya menjadi lebih positif atau lebih mendukung terhadap upaya pencegahan anemia deisiensi besi. Hal ini sejalan dengan penelitian dari Nuryani \& Paramata (2018) bahwa pendidikan kesehatan dapat meningkatkan skor sikap pada anak sekolah yakni 70,3\% naik menjadi $75 \%$ setelah diberikan pendidikan kesehatan. Upaya Pendidikan kesehatan merupakan salah satu cara untuk meningkatkan pengetahuan dan pemahaman remaja 
putri tentang pentingnya pencegahan anemia defisiensi besi sejak dini.

Dari hasil uji statistic wilcoxon sign rank test didapatkan $\mathrm{Z}_{\text {hitung }}=6.151>\mathrm{Z}_{\text {tabel }}=1.645$ Pvalue $=$ $0.000<\alpha 0.05$ artinya bahwa edukasi melalui media sosial line dapat mempengaruhi sikap remaja putri tentang pencegahan anemia defisiensi besi. Hal ini disebabkan karena pengetahuan dari remaja setelah diberikan edukasi meningkat sehingga akan mempengaruhi sikap remaja putri untuk menuju hidup yang lebih baik dan sehat. Hal ini sejalan dengan penelitian Salsabilla (2018) yang meneliti pengaruh edukasi melalui media line messeger terhadap pengetahuan dan sikap remaja putri di Kota Surakarta yang menunjukkan hasil terdapat peningkatan skor rata-rata sikap sebelum dan sesudah perlakuan sebesar 16,62. Terbukti bahwa pendidikan kesehatan dapat meningkatkan sikap remaja putri menjadi lebih baik (Notoatmojo, 2012).

\section{KESIMPULAN}

Ada pengaruh edukasi kesehatan melalui media sosial Line terhadap sikap remaja putri tentang pencegahan anemia defisiensi besi di SMP Negeri 2 Rendang. Hasil penelitian ini diharapkan dapat diaplikasikan dalam upaya meningkatkan pencegahan anemia defisiensi besi dengan menyelenggarakan kegiatan edukasi kesehatan melalu media sosial.

\section{DAFTAR PUSTAKA}

1. Arisudhana, G. A. B. (2017). Pengaruh Layanan Pesan Singkat Berbasis Edukasi terhadap Kepatuhan Konsumsi Antiretroviral pada Orang dengan HIV/AIDS di Rumah Sakit Umum Pusat Dr. Kariadi Semarang. Universitas Diponogoro.

2. Azwar, S. (2015). Sikap Manusia Teori dan Pengukurannya (2nd ed.). Pustaka Pelajar.

3. Direktorat Jenderal Kesehatan Masyarakat. (2016a). Pedoman Pencegahan dan Penanggulangan Anemia pada Remaja Putri dan Wanita Usia Subur(WUS). Jakarta: Kemenkes RI.
4. Fakhidah, L.N., \& Putri,K.S.E. (2016).Faktorfaktor yang berhubungan dengan kejadian Anemia pada Remaja Putri. Maternal,1(1), 60-66.

5. Mariyaningsih, D. (2018). Pengaruh Pendidikan Kesehatan dengan Media Komik Terhadap Pengetahuan dan Sikap Siswi Tentang Tablet Tambah Darah dan Anemia di SMP Negeri 2 Sragen. Universitas Muhamadiyas Surakarta.

6. Merryana, A., \& Wirjatmadi, B. (2013). Pengantar Gizi Masyarakat (1st ed.). Jakarta: Kencana.

7. Notoatmodjo, S. (2012). Promosi Kesehatan Teori dan Aplikasi. Jakarta: Rineka Cipta.

8. Pakar. (2018). Line,Aplikasi yang Didominasi Pengguna Remaja. Retrieved July 15, 2019, from https://pakar.co.id/2018/03/02/line-aplikasi-yangdidominasi-pengguna-remaja/

9. Priyanto, L. D. (2018). Hubungan Umur,Tingkat Pendidikan dan Aktivitas Santriwati Husada dengan Anemia. Jurnal Berkala Epidemiologi, 139-146.

10. Secsio, W., Putri, R., Nurwati, R. N., \& S, M. B. (2016). Pengaruh Media Sosial Terhadap Perilaku Rremaja. PROSIDING KS: RISET \& PKM, 3, 1154.

11. Tarwoto. (2013). Buku saku Anemia pada Ibu Hamil : Konsep dan Penatalaksanaan. TIM.

12. Wawan, A. (2019). Teori \& Pengukuran Pengetahuan, Sikap dan Perilaku Manusia. Yogyakarta: Nuha Medika.

13. Widyantari, N. P. S., Wijaya I. P. A., \& Susila, I M. D. P. (2019). Hubungan Tingkat Pengetahuan Tentang Menopause Dengan Kecemasan Menghadapi Menopause Pada Ibu Pembinaan Kesejahteraan Keluarga. Journal Center of Research Publication in Midwifery and Nursing, 3 (2), 56-59

14. Yaumi, M. (2018). Media \& Teknologi Pembelajaran. (F. Siti, Ed.). Jakarta: Pranadamedia Group. 